\title{
F Plasmid, a Co-integrate of Two Major Replicons but their Functional States Controlled by the Transposon Tn1000 in E. coli K-12
}

\section{Sunil Palchaudhuri*}

Professor, WSU School of Medicine, Detroit USA and Chairman, Atlanta Health

Centre, Kolkata India

*Corresponding Author: Sunil Palchaudhuri, Professor, WSU School of Medicine, Detroit USA and Chairman, Atlanta Health Centre, Kolkata India.
Received: February 22, 2021

Published: March 19, 2021

(C) All rights are reserved by Sunil

Palchaudhuri.
In 1946, two American investigators Lederberg and Tatum find the maleness ( $\mathrm{F}$ factor) in their laboratory strain of E. coli $\mathrm{K}-12$ but the major questions remain ignored. Where does such maleness come from? Answer to such a relevant question is now provided by the two review writers from their English dictionary: SERENDIPITY. In such a $E$. coli $\mathrm{K}-12 \mathrm{~F}^{+}$male the sex factor $\mathrm{F}$ is not integrated into its host chromosome but it prevails with the host chromosome in such a way, their progeny are also F+ males.

The sex factor is a live bio-macromolecule (100Kb long) and the host $E$. coli $\mathrm{K}-12$ chromosome is of length $4736 \mathrm{~Kb}$. These two biomacromolecules, capable of carrying genes (or operons). F contains three mobile DNA elements :two insertion sequences of fixed lengths IS2, IS3 (1.3 or $1.4 \mathrm{~Kb}$ ) and one transposon Tn 1000 of length $5.7 \mathrm{~Kb}$.In fact these mobile DNA elements played a primary role in the development of E. coli K-12 genetics and the linkage map has played to understand the metabolic pathways. E. coli $\mathrm{K}-12$ is stable laboratory strain with one origin of replicon at $84.5 \mathrm{~min}$ locus but its sex factor $\mathrm{F}$ has two replicons. $\mathrm{F}$ is born in the research laboratory of USA but the second one, the antibiotic resistance plasmid is activated in Tokyo hospitals by the abuse of ampicillin for years but really the Shigella flexneri declares its victory in 1960. Japanese clinicians accept the defeat but the question arises if our pathogens keep defeating our miracle drugs (antibiotics), then do we have any alternative therapy? Answer is not but our combination therapy? That might be alright but again how long? Our infectious disease physicians are happy but very soon they started increasing the dose and duration to save the lives of patients. They don't have much time to run after any new therapy! Now in 2011 Palchaudhuri., et al. have found that fortunately these pathogens have xylitol loci and may form a derivative to develop a birth control for these pathogens. What we want to know that we must find an alternative therapy because our big manufacturing companies have given up in the battle with serious pathogens who are capable of winning in the battle with human drugs. Its second replicon is the seed of our antibiotic resistance crisis. These two replicons are not allowed to replicate simultaneously but strictly controlled by the transposon Tn1000. My research articles already published allow me to go one step beyond that the transposon Tn1000 (also known as gamma delta) has a potential to control replicon's copy number. Based on all the data available I like to propose that we must accept that $E$. coli $\mathrm{K}-12$ sex factor $\mathrm{F}$ is not just one replicon like its host $E$. coli $\mathrm{K}-12$ chromosome but $\mathrm{F}$ is a co-integrate of two major replicons but one of these replicons remains in a latent phase or silent phase. The location of these two replicons in F plasmid as shown in the linkage map of F plasmid (Figure 1) are stringently controlled by the transposon Tn1000. From now on F plasmid should be recognized as F co-integrate. 


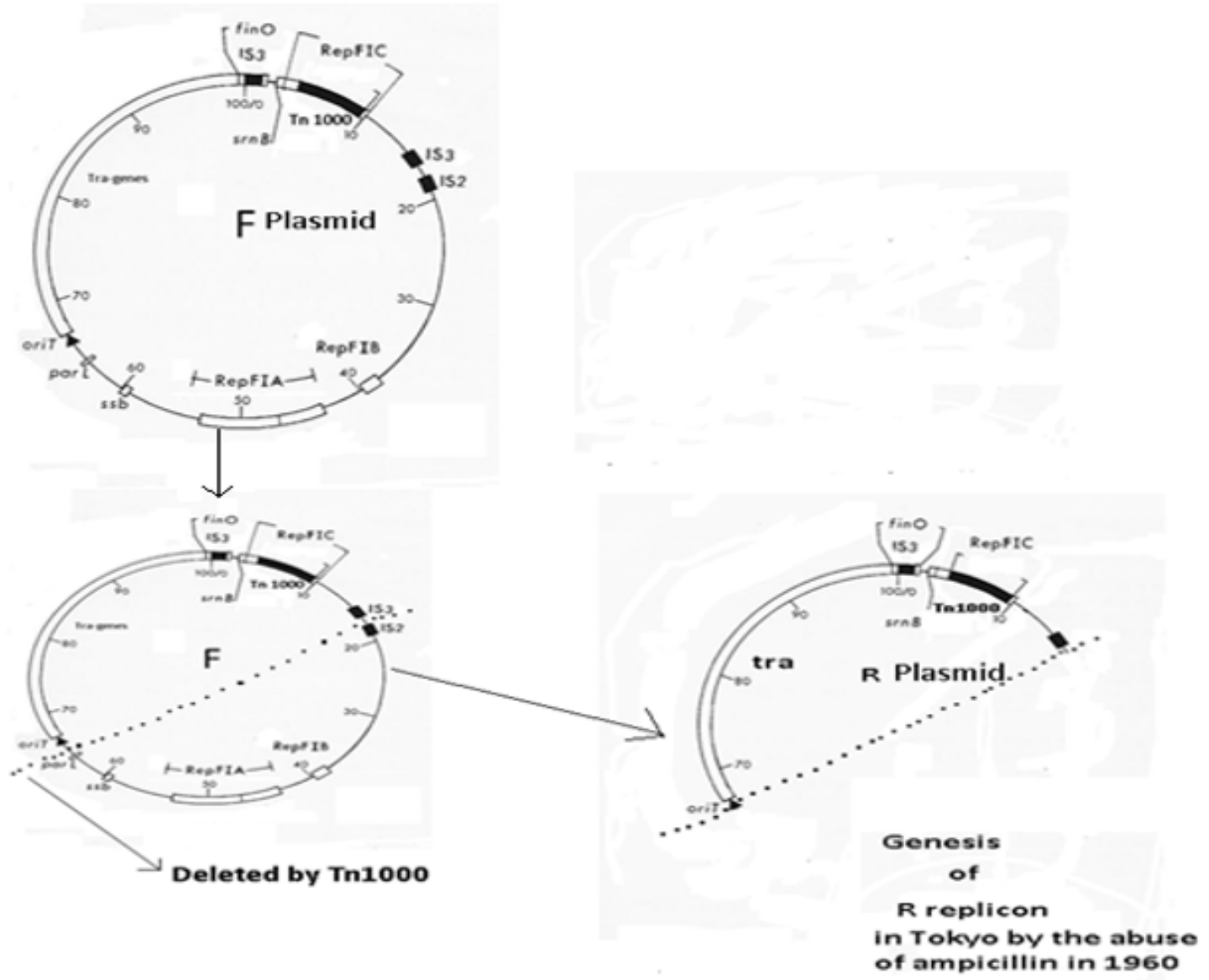

Figure 1: Linkage map of F plasmid specifying the locations of two major replicons, F plasmid replicon (RepF1A) and the R plasmid replicon (RepF1C inactivated by the insertion of Tn1000).By the abuse of ampicillin in Japan, the F1C is activated following the homologous recombination between $\mathrm{Tn} 1000$ and Tn3 carrying the gene for beta lactamase. (ampicillin resistance transposon)

\section{Assets from publication with us}

- Prompt Acknowledgement after receiving the article

- Thorough Double blinded peer review

- Rapid Publication

- Issue of Publication Certificate

- High visibility of your Published work

Website: www.actascientific.com/

Submit Article: www.actascientific.com/submission.php

Email us: editor@actascientific.com

Contact us: +919182824667 